\title{
ETIKA BERBANGSA DAN BERNEGARA DALAM ISLAM
}

\author{
Usman Sutisna \\ Universitas Indraprasta (UNINDRA) PGRI Jakarta \\ Email: usmansutisna09@yahoo.com
}

\begin{abstract}
Abstrac
This article aims to be a guideline for the general public about how we behave and uphold Islamic religious values regarding the ethics of the nation and state. This is felt to be quite important by paying attention to the phenomena and the many cases related to the fading of understanding as well as awareness as citizens who must have ethics in doing all actions that are responsible for the good and progress of the nation. Modernization and the rapid flow of globalization contribute to the weakening of public awareness in upholding the values and norms that must be a reference in behavior, so these conditions must require special attention for us all in order to maintain the integrity and national unity, especially our nation is a nation that is very diverse in all lines, both religion, race, ethnicity, culture and between groups.
\end{abstract}

Keyword: Ethics, National and State, Islam

\begin{abstract}
Abstrak
Artikel ini bertujuan untuk menjadi pedoman bagi masyarakat secara umum tentang bagaimana cara kita bersikap dan menjunjung tinggi nilai-nilai Agama Islam tentang etika berbangsa dan bernegara. Hal ini dirasakan cukup penting dengan memperhatikan fenomena dan banyaknya kasus-kasus yang berkaitan dengan pudarnya pemahaman sekaligus kesadaran sebagai warga negara yang harus memiliki etika dalam melakukan segala perbuatan yang bertanggung jawab bagi kebaikan dan kemajuan bangsa. Modernisasi dan arus globalisasi yang sangat pesat turut menyumbang faktor melemahnya kesadaran masyarakat dalam menjunjung tinggi-tinggi nilai dan norma-norma yang harus menjadi acuan dalam bertingkah laku, sehingga kondisi seperti ini harus memerlukan perhatian khusus bagi kita semua dalam rangka menjaga keutuhan dan persatuan bangsa, terlebih bangsa kita adalah bangsa yang sangat majemuk di semua lini, baik agama, ras, suku, budaya dan antar golongan.
\end{abstract}

Keyword: Etika, Berbangsa dan bernegara, Islam

\section{A. Pendahuluan}

Modernisasi dan arus globalisasi hari ini dirasakan sangat berdampak pada perubahan tingkah laku manusia pada umumnya. Bak pisau bermata dua kemajuan tersebut selalu membawa dampak positif dan negatif pada tingkah laku manusia, terlebih di dunia media sosial. 
Di Indonesia dalam kurun waktu 10 tahun dewasa ini kita bisa menyaksiakan betapa mengerikan dampak media soasial yang mampu memporak porandakan nilai-nilai dan etika berbangsa dan bernegara. Pergolakan politik yang disebabkan pemilu baik kepala daerah maupun pilpres, kasus radikalisme dan terorisme, dan banyak lagi kasus-kasus personal yang sedikit banyak mempengaruhi tatanan kehidupan berbangsa dan bernegara di tanah air kita tercinta ini.

Islam adalah agama yang diturunkan oleh Allah Swt kepada Nabi Muhammad Saw sebagai nabi dan utusan Allah Swt sebagai petunjuk hidup umat manusia (hudan li an-nas). Agama Islam hadir ke tengah umat manusia sebagai petunjuk karena ajaran-ajarannya bersifat universal, mengatur seluruh aspek kehidupan manusia baik aspek mikro maupun makro.Aspek makro, Islam mengatur tatanan kehidupan dalam aspek terkecil dalam kehidupan manusia seperti mengatur tentang etika bersilaturahim, bertetangga, belajara dan sebagainya.Sedang dalam aspek makro, Islam mengatur tatanan kehidupan manusia dalam aspek terluas dalam kehidupan manusia salah satu di antaranya adalah etika berbangsa dan bernegara.

Etika berbangsa dan bernegara sangat diperlukan dalam kehidupan manusia karena tanpa etika tersebut maka kehidupan berbangsa dan bernegara tidak akan berjalan dengan tentram, damai, dan rukun. Oleh karena itu, sebagai warga negara Indonesia sekaligus sebagai seorang muslim maka sangat penting memahami dan merealisasikan pentingnya etika dalam kehidupan berbangsa dan bernegara karena pada hakikatnya ajaran Islam yang dibawakan oleh Nabi Muhammad Saw memiliki misi profetis untuk menyempurnakan akhlak mulia maka dengan memahami dan merealisasikan etika dalam berbangsa dan bernegara pada hakikatnya kita sedang merealisasikan ajaran Islam itu sendiri.

\section{B. Pengertian Etika Berbangsa dan Bernegara}

Secara etimologi kata "etika" berasal dari Bahasa Yunani yang terdiri dari dua kata yaitu ethos dan ethikos. Ethos berarti sifat, watak kebiasaan, tempat yang biasa. Ethikos berarti susila, keadaban, kelakuan dan perbuatan yang baik. ${ }^{1}$ Istilah lainnya yang memiliki makna hampir sama dengan etika adalah moral. Moral berasal dari kata Latin: Mos (bentuk tunggal), atau mores (bentuk jamak) yang berarti adat istiadat, kebiasaan, kelakuan, watak, tabiat, akhlak, cara hidup.

\footnotetext{
${ }^{1}$ Loren, Bagus. Kamus Filsafat. (Jakarta: PT Gramedia Pustaka, 2009).h. 217
} 
Secara terminologis, etika adalah ilmu tentang baik buruknya suatu perbuatan manusia atau dalam kata lain etika digunakan untuk meninjau perbuatan manusia dari sisi keilmuan. Dalam filsafat, etika disebut sebagai filsafat moral, yakni studi yang sistematik tentang sifat dasar dari berbagai konsep nilai baik dan buruk, benar dan salah suatu perbuatan manusia. Etika juga sering diartikan sebagai aturan yang tidak tertulis dimana setiap orang diharapkan untuk mematuhinya.

Dalam Bahasa Inggris, istilah bangsa dikenal dengan nama "nation" yang memiliki dua pengertian, yakni pengertian antropologissosiologis dan politis. Dalam pengertian antropologis dan sosiologis, bangsa adalah suatu masyarakat yang merupakan suatu persekutuan hidup yang berdiri sendiri dan masing-masing merasa satu kesatuan ras, bahasa, agama, sejarah dan istiadat. Adapun yang dimaksud bangsa dalam pengertian politik adalah masyarakat dalam suatu daerah yang sama dan mereka tunduk kepada kedaulatan negaranya sebagai suatu kekuasaan tertinggi ke dalam dan ke dalam. ${ }^{2}$ Dengan demikian dapat dikatakan bahwa bangsa adalah sekumpulan manusia yang memiliki kesamaan sejarah, asal keturunan, agama, adat istiadat, bahasa dan lain sebagainya yang hidup dalam suatu wilayah tertentu dan dalam jangka waktu tertentu.

Istilah negara atau "state" berasal dari Bahasa Latin "status" atau "statum" yang berarti menempatkan dalam keadaan berdiri, membuat berdiri, dan menempatkan. Kata status sendiri dalam Bahasa Latin klasik berarti sesuatu yang memiliki sifat-sifat tegak dan tetap. ${ }^{3}$ Sedangkan menurut para ahli seperti yang diungkapkan oleh George Jellinek, negara adalah organisasi kekuasaan yang dari sekelompok manusia yang mendiami wilayah tertentu. Dari penjelasan di atas dapat disimpulkan bahwa etika berbangsa dan bernegara adalah suatu aturan yang merupakan keharusan bagi seorang warga negara dalam menjalankan aktivitasnya dalam berbangsa dan bernegara.

\section{Dasar-dasar Kehidupan Berbangsa dan Bernegara Dalam Islam}

Secara kodrati, manusia ditakdirkan oleh Allah Swt bersuku-suku dan berbangsa-bangsa tujuannya adalah agar saling mengenal sebagaimana yang tercantum dalam Al-Qur'an surat Al-Hujurat ayat 13:

${ }^{2}$ Abudin, Nata. Akhlak tasawuf dan Karakter Mulia. (Jakarta: PT Gramedia Pustaka Utama, 2012). h. 75

${ }^{3}$ Isjwara, F. Pengantar Ilmu Politik (Bandung : Bina Cipta, 2011). h. 92 


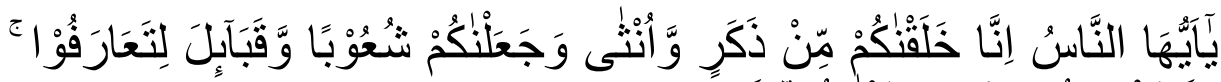

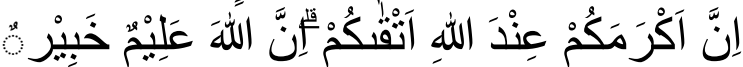

"Wahai manusia!Sungguh, Kami telah menciptakan kamu dari seorang laki-laki dan seorang perempuan, kemudian Kami jadikan kamu berbangsa-bangsa dan bersuku-suku agar kamu saling mengenal.Sesungguhnya yang paling mulia di antara kamu di sisi Allah ialah orang yang paling bertakwa. Sungguh, Allah Maha Mengetahui, Mahateliti."

Tidak hanya untuk saling mengenal saja akan tetapi juga untuk saling memberi manfaat. Hal ini sebagaimana yang diungkapkan oleh Quraish Shihab ketika menjelaskan ayat tersebut bahwa semakin kuat sikap pengenalan satu pihak kepada selainnya, semakin terbuka peluang untuk saling memberi manfaat.Karena itu ayat di atas menekankan perlunya saling mengenal. ${ }^{4}$ Apalah arti perkenalan jikalau tidak saling memberikan manfaat. Oleh karena itu dalam Islam manusia terbaik adalah manusia yang memberikan manfaat untuk orang lain sebagaimana hadits Nabi Saw:

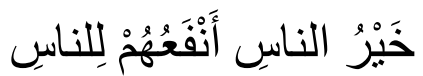

"Sebaik-baik manusia adalah yang paling bermanfaat bagi manusia" (HR. Ahmad, ath-Thabrani, ad-Daruqutni. Hadits ini dihasankan oleh al-Albani di dalam Shahihul Jami'no: 3289).

Dengan memahami adanya keanekaragaman manusia maka tentu kita akan memahami pentingnya tatanan kehidupan manusia khususnya dalam berbangsa dan bernegara. Terkait hubungan manusia dalam berbangsa dan bernegara, pertama Islam memerintahkan kepada orang beriman agar taat kepada Allah, taat kepada Rasul-Nya dan taat kepada pemerintah. Hal ini dijelaskan dalam Al-Qur'an surat An-Nisa ayat 59:

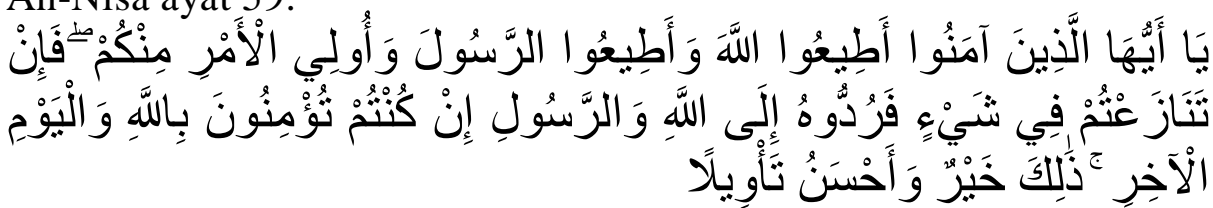

"Hai orang-orang yang beriman, taatilah Allah dan taatilah Rasul (Nya), dan ulil amri di antara kamu. Kemudian jika kamu berlainan pendapat tentang sesuatu, maka kembalikanlah ia kepada Allah (Al Quran) dan Rasul (sunnahnya), jika kamu benar-benar beriman

\footnotetext{
${ }^{4}$ M. Quraish, Shihab. Tafsil Al-Misbah. (Jakarta: Lentera Hati, 2002), h. 262
} 
kepada Allah dan hari kemudian. Yang demikian itu lebih utama (bagimu) dan lebih baik akibatnya."

Ayat ini dan ayat sebelumnya (58) mengandung tentang prinsipprinsip kesejahteraan umat Islam khususnya dalam urusan kekuasaan pemerintahan. Prinsip-prinsip tersebut adalah (1) taat kepada Allah sebagaimana tercantum dalam Al-Qur'an, (2) taat kepada Rasulullah sebagaimana terdapat dalam sunnahnya yang sahih, (3) taat kepada pemegang kekuasaan, selagi mereka bagian dari kaum muslim dan selama perintahnya tidak bertentangan dengan Allah dan Rasul-Nya, (4) mengembalikan kepada Allah (Al-Qur'an) dan Rasul-Nya (sunnah), jika terjadi perselisihan. Kedua, Islam mengatur akan pentingnya menjaga persatuan dan kesatuan dalam kehidupan berbangsa dan bernegara. Negara adalah tempat dimana suatu bangsa tinggal dan hidup sehingga tentram tidaknya dan nyaman tidaknya sangat tergantung dari kondisi persatuan dan kesatuan. Negara yang persatuan dan kesatuannya kuat akan cenderung dalam kondisi yang aman dan tentram, oleh karena itu dalam Islam persatuan dan kesatuan menjadi hal yang sangat penting bagi kehidupan manusia. Pada ayat di atas telah dijelaskan bahwa perbedaan itu merupakan kodrat Allah dan tidak ada satu orang pun yang mampu untuk menghapus dan menghilangkan perbedaan tersebut.Perbedaan menjadikan seseorang berlomba-lomba untuk menjadi yang terbaik (muttaqin) bukan menjadikan rusak dan runtuhnya persatuan dan kesatuan. Al-Qur'an menjelaskan tentang pentingnya persatuan dan kesatuan sebagaimana yang tercantum dalam Al-Qur'an surat Ali Imran ayat 103:

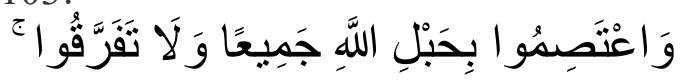

"Dan berpeganglah kamu semuanya kepada tali (agama) Allah, dan janganlah bercerai berai"

Ayat di atas memberikan penjelasan kepada kita untuk senantiasa berpegang teguh kepada ajaran-ajaran Allah (Islam) yang menjadi pijakan utama dalam menjalani kehidupan di dunia dan Allah memerintahkan kita untuk memperkuat persatuan dan kesatuan dan menghindarkan dari segala perpecahan yang sangat berdampak bagi kehidupan manusia itu sendiri.

Ketiga, Islam memerintahkan kepada orang beriman untuk membela tanah air. Tanah air yang menjadi tempat hidup dan mencari penghidupan harus dibela bahkan membela tanah air merupakan bagian daripada iman atau dengan kata lain membela tanah air adalah bagian 
dari konsekuensi keimanan seseorang. Nabi Muhammad Saw telah memberikan teladan kepada kita dalam mencintai tanah air. Beliau sangat cinta terhadap dua kota, yakni Mekkah dan Madinah. Mekkah adalah tempat beliau lahir dan Madinah adalah tempat dimana beliau ketika pertama kali hijrah diterima oleh masyarakat Madinah dan tempat dimana Rasulullah membangun peradaban. Al-Qur'an memberikan petunjuk tentang pentingnya mencintai tanah air sebagaimana yang tercantum dalam Al-Qur'an surat Al-Qashshash ayat 85:

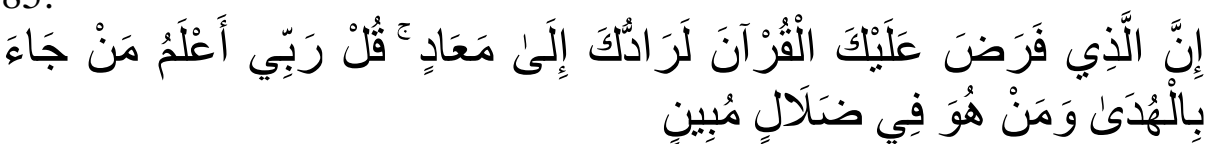

"Sesungguhnya yang mewajibkan atasmu (melaksanakan hukumhukum) Al-Qur'an, benar-benar akan mengembalikan kamu ke tempat kembali. Katakanlah: "Tuhanku mengetahui orang yang membawa petunjuk dan orang yang dalam kesesatan yang nyata."

Ibnu 'Abbas menyatakan bahwa ayat di atas turun di Juhfah dekat Mekkah dalam perjalanan Nabi menuju ke Madinah.Ketika itu beliau dalam bahaya.Hati dan pandangan beliau tertuju ke negeri yang dicintainya dan yang terasa bagi beliau sangat berat untuk ditinggalkan, seandainya bukan karena dakwah Islam lebih penting dan mulia bagi beliau dari negeri dan tumpah darahnya. Dalam artian beliau sangat mencintai kota Mekkah namun karena perintah Allah dan dakwah Islam maka beliau harus meninggalkan kota yang sangat dicintainya. Dengan demikian, cinta tanah air adalah telah dicontohkan oleh Rasulullah sendiri.

Keempat, memecahkan persoalan umat dengan jalan musyawarah.Asal kata musyawarah yang sudah menjadi Bahasa Indonesia tersebut adalah asywara yang berarti menampakkan sesuatu atau mengeluarkan madu dari sarang lebah. Musyawarah berarti menampakkan sesuatu yang semula tersimpan atau mengeluarkan pendapat (yang baik) kepada pihak lain. Orang yang bermusyawarah laksana orang yang minum madu. ${ }^{5}$ Musyawarah dalam konteks kehidupan sosial sangat penting terutama dalam rangka mencari solusi atas berbagai permasalahan karena dengan musyawarah maka akan ditemukan berbagai pandangan atau pendapat dari hasil kerja keras akal sehingga bisa menjadi alternative bagi berbagai persoalan. Dalam

\footnotetext{
${ }^{5}$ Achmad Haris, Zubair. Kuliah Etika. (Jakarta: Rajawali Press, 2012). h. 217
} 
Islam, setiap persoalan yang terkait dengan orang lain harus diselesaikan dengan jalan musyawarah karena dengan jalan ini akan adanya keterbukaan dan kerelaan. Sebaliknya jika persoalan diselesaikan dengan sepihak sudah dipastikan akan terjadi keterpaksaan yang pada akhirnya bukan solusi yang didapatkan akan tetapi justru masalah baru. Oleh karena itu, Islam menempatkan musyawarah sebagai cara yang paling penting untuk menyelesaikan persoalan salah satunya yang terdapat dalam Al-Qur'an surat Ali Imran ayat 153:

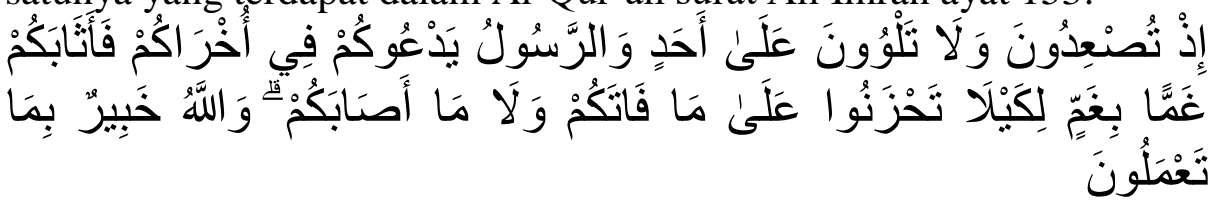

"(Ingatlah) ketika kamu lari dan tidak menoleh kepada seseorangpun, sedang Rasul yang berada di antara kawan-kawanmu yang lain memanggil kamu, karena itu Allah menimpakan atas kamu kesedihan atas kesedihan, supaya kamu jangan bersedih hati terhadap apa yang luput dari pada kamu dan terhadap apa yang menimpa kamu. Allah Maha Mengetahui apa yang kamu kerjakan."

Ayat yang menjadi pembahasan ini turun setelah peristiwa Uhud.Sebelum perang dilakukan Nabi mengajak para sahabatnya untuk bermusyawarah tentang bagaimana menghadapi musuh. Pada musyawarah tersebut, Nabi mengikuti pendapat mayoritas sahabat, meskipun hasilnya sungguh sangat menyedihkan yang berakhir dengan kakalahan kaum muslim. Saat berakhir itulah Nabi memutuskan untuk menghapuskan musyawarah.Namun dengan turunnya ayat ini, Allah berpesan kepada Nabi bahwa tradisi musyawarah (yang luhur tersebut) tetap harus dipertahankan dan dilanjutkan meski terbukti hasil keputusannya (kadang) keliru). Ayat di atas juga menjelaskan bahwa lapangan (obyek) musyawarah adalah segala masalah yang belum terdapat petunjuk agama secara jelas dan pasti sekaligus berkaitan dengan kehidupan duniawi.Sedangkan orang-orang yang bisa dan layak diajak bermusyawarah sebagaimana dalam hadits Nabi ketika berpesan kepada Ali adalah orang yang tidak berperedikat penakut, kikir dan berambisi. $^{6}$

\section{Etika Seorang Muslim Dalam Berbangsa dan Bernegara}

${ }^{6}$ Moch, Saragih, Kusnardi, Bintan D, Ilmu Negara (Jakarta: Gaya Media Pratama, 2015). h. 142 
Dalam kondisi apapun, Allah Swt memerintahkan kepada umat Islam untuk senantiasa berakhlak yang baik, termasuk dalam kehidupan berbangsa dan bernegara.Namun, sebelum menjelaskan tentang etika atau lebih khusus lagi akhlak dalam bernegara alangkah baiknya dijelaskan tentang beberapa hak dan kewajiban seorang warga negara dalam konteks Negara Kesatuan Republik Indonesia.Hak warga negara dapat diartikan sebagai sesuatu yang dapat dimiliki oleh setiap warga negara dari negaranya yang diatur oleh undang-undang sedangkan kewajiban warga negara adalah sesuatu yang harus dilakukan oleh setiap warga negara terhadap negaranya. Adapun hak-hak sebagai warga negara tercantum dalam UUD 1945 diantaranya adalah hak untuk mendapatkan pekerjaan yang layak (Pasal 27 Ayat 2), hak untuk ikut serta dalam membela negara (Pasal 27 Ayat 3), hak untuk berpendapat (Pasal 28), hak untuk mendapatkan kebebasan beragama (Pasal 29), hak dalam pertahanan dan keamanan (Pasal 30 Ayat 1), hak untuk mendapatkan pengajaran (Pasal 31 Ayat 1), hak untuk mengembangkan dan memajukan kebudayaan (Pasal 32 Ayat 1), hak untuk mendapatkan kesejahteraan ekonomi dan sosial (Pasal 33), dan hak bagi fakir miskin dan orang-orang terlantar untuk mendapatkan perhatian dari negara. Sedangkan kewajiban warga negara terhadap negaranya adalah menjunjung tinggi hukum dan pemerintahan tanpa kecuali (Pasal 27 Ayat 1), kewajiban membela negara (Pasal 27 Ayat 3), dan ikut serta dalam usaha pertahanan dan keamanan negara (Pasal 30 Ayat 1). Dengan penjelasan tersebut dapat dikatakan bahwa adanya hubungan timbal balik antara negara dan warga negaranya, oleh karena itu sudah sepatutnya sebagai seorang muslim untuk menjalankan segala kewajiban-kewajiban kita sebagai warga negara.

Secara garis besar, setidaknya ada tiga etika seorang muslim dalam kehidupan berbangsa dan bernegara, yaitu menegakkan keadilan dan kebenaran, menegakkan nilai-nilai kemanusiaan, dan mewujudkan kemaslahatan umat.

Pertama, menegakkan keadilan dan kebenaran. Dalam kehidupan, kebenaran dan keadilan adalah sesuatu yang paling dicari oleh setiap manusia bahkan kehidupan manusia itu sendiri disebut sebagai proses dalam mencari keadilan dan kebenaran. Islam adalah agama yang akan selalu berpihak kepada keadilan dan kebenaran bahkan menegakkan keadilan dan kebenaran adalah kewajiban bagi setiap muslim kapan saja dan dimana saja. Karena saking pentingnya keadilan dalam kehidupan manusia, Allah Swt memerintahkan kepada 
orang-orang beriman agar selalu menegakkan keadilan dan kebenaran sebagaimana yang tercantum dalam Al-Qur'an surat Al-Maidah ayat 8:

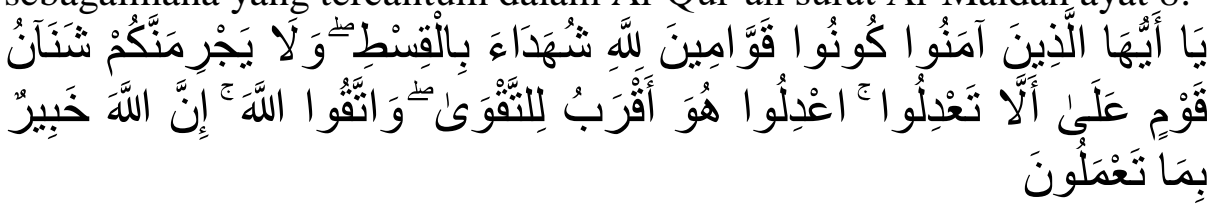

"Hai orang-orang yang beriman hendaklah kamu jadi orang-orang yang selalu menegakkan (kebenaran) karena Allah, menjadi saksi dengan adil.Dan janganlah sekali-kali kebencianmu terhadap suatu kaum, mendorong kamu untuk berlaku tidak adil.Berlaku adillah, karena adil itu lebih dekat kepada takwa.Dan bertakwalah kepada Allah, seseungguhnya Allah Maha Mengetahui apa yang kamu kerjakan."

Kedua, menegakkan nilai-nilai kemanusiaan. Secara genealogis, manusia diciptakan oleh Allah Swt dari jenis yang sama, dari nenek moyang yang sama dan dari bahan yang sama. Persamaan inilah yang menjadi dasar pentingnya menegakkan nilai-nilai kemanusiaan. Penegakkan nilai-nilai kemanusiaan dalam Islam menjadi tujuan diturunkannya syariat (maqashidus syari'ah) yang mencakup lima hal, yaitu hak beragama (hifdhzud din), hak hidup (hifdhzun nafs), hak intelektual (hifdhzul 'aql), hak kekayaan (hifdhzul maal), dan hak keturunan (hifdhzun nasl). Secara sosiologis, ajaran Islam akan mengerucut pada lima hal tersebut karena lima hal tersebut merupakan sesuatu yang sangat primer dan utama dalam kehidupan manusia. Dengan demikian, seorang muslim berkewajiban menegakkan pentingnya nilai-nilai kemanusiaan dalam kehidupan berbangsa dan bernegara apabila ini terwujud maka cita-cita menjadi negara yang baldatun thayyibatun warabbun ghafur akan tercapai.

Ketiga, mewujudkan kemaslahatan umat.Inti daripada syariat Islam adalah terwujudnya kemaslahatan umat. Kemaslahatan ini bisa bersifat materil maupun non materil, baik untuk dirinya dan juga untuk orang lain. Kemaslahatan adalah sesuatu yang bersifat universal, berlaku dimana saja dan kapan sehingga harus diperjuangkan oleh setiap manusia.Dalam berbangsa dan bernegara, kebijakan atau keputusan hukum harus mengacu kepada terwujudnya kemaslahatan umat bahkan dalam kaidah fikih dikatakan bahwa kebijakan seorang pemimpin harus dikaitkan dengan kemaslahatan. Dengan demikian, peran serta seorang muslim dalam politik secara umum dan kebijakan secara khusus adalah ikut serta mendorong terwujudnya kemaslahatan umat. 


\section{E. Pilar Kehidupan Berbangsa dan Bernegara di Indonesia dalam Perspektif Islam}

Dalam konteks Negara Kesatuan Republik Indonesia (NKRI), terdapat empat pilar yang menjadi pondasi dalam kehidupan berbangsa dan bernegara yaitu Pancasila, UUD 1945, NKRI, dan Bhineka Tunggal Ika.Namun pertanyaannya apakah keempat pilar tersebut sejalan dengan ajaran-ajaran Islam?Untuk menjawab pertanyaan tersebut maka alangkah baiknya kita pahami satu persatu dari komponen keempat pilar tersebut.

Pertama, Pancasila. Pancasila merupakan pandangan hidup bangsa Indonesia yang dimana nilai-nilai yang terdapat di dalamnya diambil dari karakter dan pandangan hidup dari bangsa Indonesia itu sendiri. Terdapat lima sila dalam Pancasila, yaitu (1) Ketuhanan Yang Maha Esa, (2) Kemanusiaan yang adil dan beradab, (3) Persatuan Indonesia, (4) Kerakyatan yang dipimpin oleh hikmat kebijaksanaan dalam permusyawaratan dan perwakilan, dan (5) Keadilan bagi seluruh rakyat Indonesia. Jika ditelusuri dan dipahami dengan seksama satu persatu maka nilai-nilai Pancasila tidak ada yang bertentang dengan ajaran-ajaran Islam atau bahkan sejalan dengan ajaran-ajaran Islam.Sila pertama Ketuhanan Yang Maha Esa merupakan esensi daripada ajaran akidah yang menjadi ajaran pokok dan utama.Sila kedua kemanusiaan yang adil dan beradab merupakan perintah Allah bahwa tegaknya keadilan dan manusia beradab merupakan perintah Allah.Sila ketiga persatuan Indonesia, Islam memerintahkan kepada umat Islam untuk mempererat silaturahim dan Islam sangat mengecam perpecahan. Sila keempat kerakyatan yang dipimpin oleh hikmat kebijaksanaan dalam permusyawaratan dan perwakilan, sila ini mengisyaratkan bahwa proses penentuan kebijakan harus melalui musyawarah dan musyawarah ini merupakan ajaran daripada Al-Qur'an. Dan kelima keadilan sosial bagi seluruh rakyat Indonesia, sila ini menunjukkan bahwa keadilan sosial merupakan tujuan daripada terbentuknya Negara Kesatuan Republik Indonesia. Dalam Islam, tegaknya keadilan dan kebenaran merupakan kewajiban setiap orang khususnya seorang muslim.

Kedua, Undang-undang Dasar 1945. Undang-undang dasar adalah hukum dasar (basic law) yang menjadi dasar pijakan bagi kehidupan bangsa Indonesia.Undang-undang ini mengatur tentang bentuk, sistem pemerintahan, pembagian kekuasaan, wewenang badanbadan pemerintahan, hak dan kewajiban warga negara, dan lain 
sebagainya. Dalam Islam, Al-Qur'an dan as-Sunnah merupakan pijakan utama, selama UUD 1945 tidak bertentangan dengan ajaran Islam maka tentu tidak menjadi masalah bahkan sebaliknya jika sesuai dengan ajaran Islam maka harus diterima dan dilaksanakan oleh setiap muslim.

Ketiga, Negara Kesatuan Republik Indonesia. Indonesia adalah negara kepulauan yang terdiri dari beraneka ragam suku, bangsa, bahasa, agama, adat, budaya dan sebagainya yang disatukan oleh kesadaran bersama sehingga disebut sebagai Negara Kesatuan Republik Indonesia.Perbedaan dalam kehidupan manusia merupakan kodrat Allah yang tidak bisa dirubah-rubah bahkan adanya keaneka ragaman ini menjadikan Indonesia sebagai negeri yang kaya. Dalam Islam, keanekaragaman tersebut bertujuan agar terjadinya saling mengenal dan bekerjasama dan keanekaragaman juga sebagai cara Allah untuk menguji siapa yang paling takwa kepada Allah. Adanya perbedaan dalam bingkai persatuan merupakan semangat yang ingin dicapai oleh ajaran Islam karena Islam sangat mengutamakan pentinya persatuan dan kesatuan.

Keempat, Bhineka Tunggal Ika. Bhineka Tunggal Ika atau yang sering kita terjemahkan sebagai berbeda tetapi tetp satu jua merupakan semboyan bangsa Indonesia untuk mempersatukan segala perbedaan yang ada dalam bangsa Indonesia seperti suku, bahasa, agama, adat, budaya dan sebagainya. Bhineka Tunggal Ika jika ditelusuri dalam ajaran Islam merupakan pengejawantahan daripada surat Al-Hujurat ayat 13. Dimana perbedaan bukanlah menjadi penghalang bagi seseorang untuk mendapatkan tempat yang mulia di sisi Allahakan tetapi ketakwaan kepada-Nya merupakan kunci untuk mendapatkan tempat yang mulia tersebut.

\section{F. Kesimpulan}

Sebagai agama universal, Islam mengatur seluruh aspek kehidupan manusia baik aspek mikro maupun makro termasuk dalam hal ini adalah terkait tentang kehidupan berbangsa dan bernegara.Ajaran Islam menekankan pentingnya etika atau akhlak dalam kehidupan berbangsa dan bernegara agar terwujudnya kehidupan yang damai, tenteram dan sentosa.Etika atau akhlak berbangsa dan bernegara dalam Islam dapat diwujudkan dengan menegakkan keadilan dan kebenaran, menegakkan nilai-nilai kemanusiaan, dan mewujudkan kemaslahatan umat.Dalam konteks Negara Kesatuan Republik Indonesia, terdapat empat pilar dalam kehidupan berbangsa dan bernegara yaitu Pancasila, UUD 1945, NKRI, dan Bhineka Tunggal 
Ika.Empat pilar tersebut jika ditelusuri dan dipahami secara mendalam maka tidak ada yang bertentangan dengan ajaran-ajaran Islam sehingga perlu didukung dan diimplementasikan oleh seluruh warga negara Indonesia. Jikapun di dalamnya terdapat kekurangan, kelemahan atau kekeliruan maka bisa direvisi sesuai dengan prosedur yang berlaku.

\section{Daftar Pustaka}

Abdul Ghofur, Waryono. Tafsir Sosial. (Yogyakarta: ElSaQ, 2005).

Bagus, Loren. Kamus Filsafat. (Jakarta: PT Gramedia Pustaka, 2009).

Isjwara, F. Pengantar Ilmu Politik (Bandung : Bina Cipta, 2011)

Kusnardi, Moch, Saragih, Bintan D, Ilmu Negara (Jakarta: Gaya Media Pratama, 2015)

(Nata, Abudin. Akhlak tasawuf dan Karakter Mulia. (Jakarta: PT Gramedia Pustaka Utama, 2012).

Nur, Aminudin, Pengantar Studi Sejarah Pergerakan Nasional (Jakarta:Pembimbing Massa, 2008)

Shihab, M. Quraish. Tafsil Al-Misbah. (Jakarta: Lentera Hati, 2002).

Zubair, Achmad Haris. Kuliah Etika. (Jakarta: Rajawali Press, 2009). 